\title{
Protictive effects of green tea and garlic on the morphological and oxidative stress changes of hippocampus in aged male and female albino rats
}

\author{
Gamal H. El-Sokkary, Al Shaimaa A. I. Alghriany* and Mona M. Atia
}

*Correspondence: alshaimaa84@yahoo.com

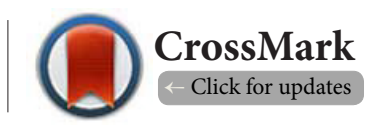

Department of Zoology Faculty of Science, Assiut University, Assiut, 71516 Egypt.

\begin{abstract}
Objective: Green tea is an extremely popular drink and particularly rich in strong antioxidants, flavonoids. Also, garlic is important dietary and has medicinal role for centuries and possess both antioxidant and antiinflammatory action in several oxidative stress conditions.

Materials and methods: Four groups of both male and female rats [young (3 months-old), aged (26 months-old), aged+green tea $(200 \mathrm{mg} / \mathrm{kg})$ and aged + garlic $(100 \mathrm{mg} / \mathrm{kg})]$ were used. Histological changes in the pyramidal cells of the hippocampus were examined. Levels of oxidized lipids (LPO), superoxide dismutase (SOD) activity and glutathione concentration (GSH) were measured in the serum.

Results: Irregular, shrinked and deeply stained large and small pyramidal cells with fragmented nuclei and basophilic cytoplasm observed in the hippocampus of aged male and female rats. Green tea and garlic administration preserve these changes in the pyramidal cells in both genders. Aging increased the level of LPO, decreased the activity of SOD and the concentration of GSH of both male and female rats versus those of young ones. Again, green tea and garlic ameliorated these changes.

Conclusion: our results showed that the protective role of green tea and garlic against oxidative stress parameters was more effective in males than females. Morphologically, garlic exerted preservation to the pyramidal cells of hippocampus more than green tea in both genders. This study suggests that the use of both green tea and garlic may inhibit the bodily changes related to aging.
\end{abstract}

Keywords: Aging, Garlic, Green tea, Lipid peroxidation, Antioxidants

\section{Introduction}

The aging process considered a unique feature of life cycle of virtually all multicellular organisms including many physiological actions to maintain the homeostasis and resulting in death. Although numerous hypotheses have been done to explain the aging process, many of them did not have sufficient empirical support to merit serious consideration [1].

It was postulated that, aging results from the accumulation of harmful effects caused by free radicals. The ability of an organism to overcome cellular damage induced by reactive oxygen species (ROS) plays a vital role in determining organismal life span [2]. ROS production by mitochondria and increased 8-oxo-dG content in the mtDNA are frequently detected in aged tissues. This suggesting that progressive accumulation of oxidative DNA damage is a contributory factor to the aging process [3]. Consistently, [4] reported that increased oxidative damage in cells is associated with aging.

The hippocampus is the site of selection of important information and consolidation of spatial memory. Environmental sensory inputs received by the cortical sensory and association areas are transmitted in sequential order via the entorhinal cortex and hippocampal formation [dentate gyrus (DG), a series of Cornu Ammonis regions (CA3, CA2, CA1), subiculum] before finally transferred back to the cortical association areas [5].

CA1 cells are essential for associating information received gradually when there are considerable temporal intervals between components of stimuli. Of note, it is possible that CA 1 and CA 3 cells have an overlapping role in memory which 
involves temporal ordering associated with spatial location [6]. Given the roles of the $C A 3$ and $C A 1$ regions in spatial memory formation, it follows that any disruption to the pyramidal cells of the CA2-CA3 and CA1 regions may cause spatial learning and memory deficits.

Garlic (Allium sativum) is important dietary and has medicinal role for centuries. The suggested pharmacological effects of garlic are hypolipidemic, hypoglycemic, anticoagulant, antihypertensive, antimicrobial, anticancer and antitumor, as an antidote for heavy metal poisoning, hepatoprotective and as an immunomodulator [7]. Organosulfur compounds, present in garlic, have significant antioxidant effects as well [8].

Green tea (Camellia sinensis) is an extremely popular drink in eastern countries, and polyphenols are natural plant flavonoids found in the tea plant leaves. Polyphenol antioxidants are known as catechins. The major tea catechins include epicatechin (EC), epigallocatechin (EGC), EC gallate (ECG) and $E G C$ gallate (EGCG). Epigallocatechingallate is the most active antioxidant of the tea catechins and is responsible for the "green tea effect." [9].

It was reported that, the polyphenols in green tea can neutralize free radicals and may reduce or even help to prevent some of the damage caused by ROS [10]. On the other hand, tea polyphenols have the ability to participate in vitamin E recycling [11]. Because of the presence of other antioxidant constituents in the green tea extract, it is more stable than pure epigallocatechingallate; one of the major constituents of green tea [12].

The aim of this study was to investigate the role of green tea extract and garlic as antioxidants against the effect of aging on the morphological changes of the hippocampus and the oxidative stress parameters (LPO, SOD and GSH) in the serum of aged male and female albino rats.

\section{Materials and methods Animals}

A total number of 160 rats ( 80 males and 80 females) used in this study. 20 males and 20 females with initial ages of 3 months (young), 60 males and 60 females with the initial age of 22 months (aged). They were purchased from Assiut University Joint Animal Breeding Unit. Care and treatment of animals was approved and practices were performed according to approval of ethics regulation at the Assiut University. The animals were kept at temperature of $23 \pm 2^{\circ} \mathrm{C}$ and light cycle of 12:12 hourslight: dark. All animals were given free access to standard chow and tap water.

\section{Chemicals}

2-thiobarbituric acid, 1,1,3,3-tetramethoxypropane, superoxide dismutase, epinephrine, glutathione, dimethyl sulfoxide and sodium dodecyl sulfate were purchased from Sigma Chemical Co. (St. Louis, MO, USA). Green tea was purchased from (Twinings of London, England). Garlic (Tomex $200 \mathrm{mg}$ tab) was purchased from Sekem Pharmacy, Egypt. All other chemicals were of highest quality available.

\section{Green tea and garlic preparations}

The leaves of green tea (Camellia Sinensis) were boiled in distilled water (1:10 w/v) 5 min twice. The solution was called unfiltered, and then filtrates were combined, concentrated, and lyophilized. Ten grams of lyophilized aqueous extract were soaked in 1 liter of boiling distilled water to make 1\% solution. The solution designated as green tea extract (GTE) was orally administered to rats by gastric tube at a dose of $200 \mathrm{mg} / \mathrm{Kg}$ [13].

Garlic (Tomex $200 \mathrm{mg}$ tab) was dissolved in distilled water and was given orally to rats by gastric tube at a dose of 100 $\mathrm{mg} / \mathrm{kg}$ [14].

\section{Experimental design and procedures}

The animals were divided into 4 groups for each gender, 20 rats for each; group 1; (3 mon- old) served as young control group (y. cont), group2; (26 mon-old) served as old group $(\mathrm{Ag})$, group 3; (26 mon-old) orally received $200 \mathrm{mg} / \mathrm{kg}$ green tea extract per day (Ag+GT), and group 4; (26 mon-old ) orally received $100 \mathrm{mg} / \mathrm{kg}$ garlic per day $(\mathrm{Ag}+\mathrm{Gr})$. The administration of green tea and garlic was repeated daily for 4 months.

\section{Hippocampus preparation}

The hippocampus specimens were fixed in formal alcohol. Blocks were made and paraffin sections were cut 5-7 $\mu \mathrm{m}$ thick and stained with haematoxylin and eosin. Sections were examined using light microscope and photographed. All methods were applied according to [15].

\section{Biochemical examination}

Blood samples were collected from rat orbital sinus for biochemical examinations. The samples were centrifuged at $2000 \mathrm{~g}$ for $15 \mathrm{~min}$ for serum separation. Lipid peroxidation product (MDA) was measured by the method according to [16]. The activity of superoxide dismutase (SOD) was measured based on [17]. The concentration of glutathione (GSH) was measured based on [18].

\section{Statistical analysis}

Results were expressed as means + SEM. Differences between means were tested by one way ANOVA followed by the student- Newman- Keul t-test.

\section{Results}

\section{Hippocampus histology}

In male rats, the hippocampus composed of polymorphic cell layer, granular layer and molecular layer (Figure 1a). The dominant neurons in the hippocampus proper are the pyramidal cells. They are highly packed and variable in sizes (small and large). These cells have large vesicular nuclei and basophilic granular cytoplasm rich in Nissl's granules and prominent processes (Figures $\mathbf{1} \mathbf{a}$ and $\mathbf{1 b}$ ). Glial cells are distributed between the neurons and in the molecular layer (Figure 1b).

In Aged group,there is a decrease in the thickness and 

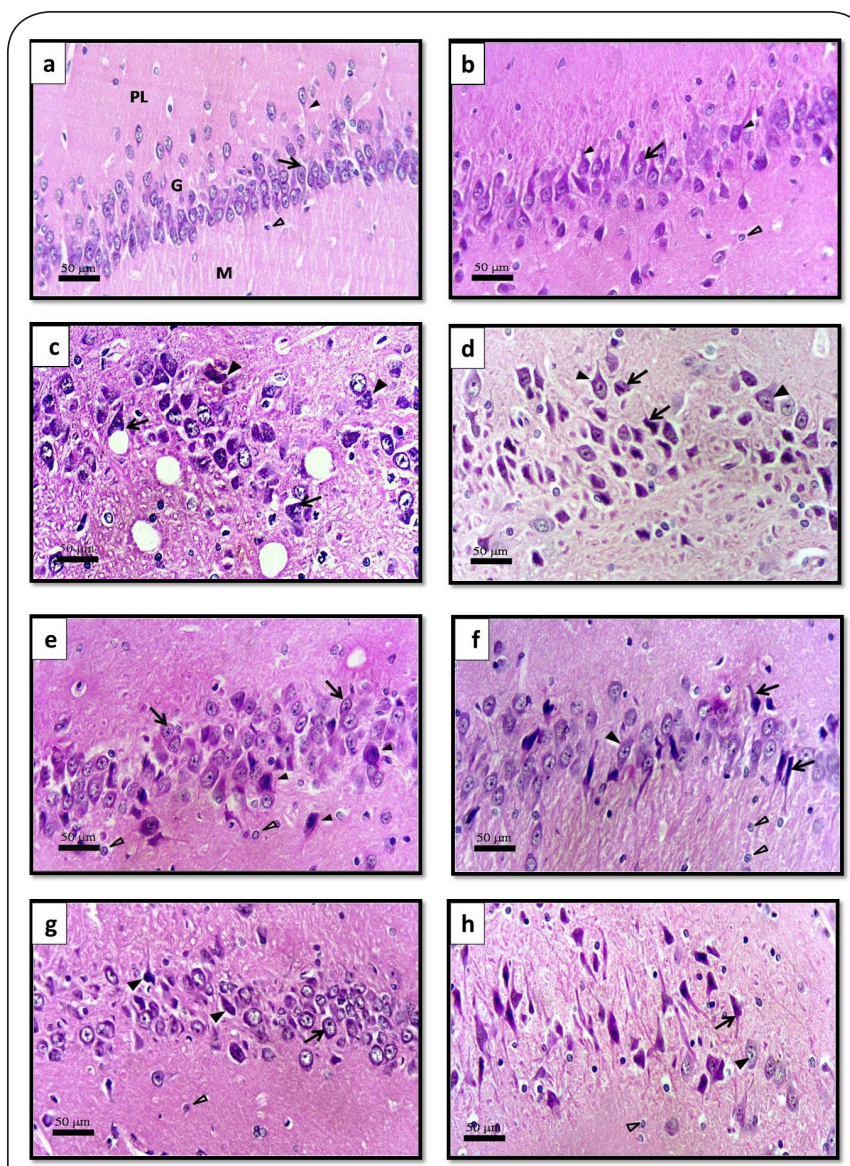

Figure 1. Photomicrographs of hippocampus proper of male rats, (a and b) for y.cont. group. a: polymorphic cell layer (PL), granular cell layer $(\mathrm{G})$,small pyramidal cell $(\uparrow)$, neural process $(\boldsymbol{\Delta})$ and glial cells $(\boldsymbol{\Delta})$. $\mathbf{b}$ : large pyramidal cell $(\uparrow)$, neural process $(\boldsymbol{\Delta})$ and glial cell $(\Delta)$. (c and $\mathbf{d})$ for Ag group. c: shrinked cells with increased spaces around and between them $(\uparrow)$, pyknotic and fragmented nuclei $(\boldsymbol{\Delta})$. d: shrinked and deeply stained pyramidal cell with pyknotic nuclei $(\uparrow)$, some cells still have normal cytoplasm, processes and nuclei $(\boldsymbol{\Delta})$. (e and f) for Ag+GT group. e: normal small pyramidal cells $(\uparrow)$,deeply stained cells with fragmented nuclei $(\boldsymbol{\Delta})$ and glial cells $(\Delta)$. f: degenerated large pyramidal cells $(\uparrow)$, glial cells $(\Delta)$ and some pyramidal cells with vesicular nuclei $(\boldsymbol{\Delta})$. ( $\mathbf{g}$ and $\mathbf{h}$ ) for $\mathrm{Ag}+\mathrm{Gr}$ group. $\mathbf{g}$ : increase in the thickness of pyramidal layer, large number of normally preserved small pyramidal cells $(\uparrow)$, some shrinked and deeply stained cells $(\boldsymbol{\Delta})$ and glial cells $(\Delta)$. h: deeply stained shrunken large pyramidal cells $(\uparrow)$, normal pyramidal cells with rounded vesicular nuclei $(\boldsymbol{\Delta})$ and glial cells $(\Delta)$. (H\&E, Bar=50 $\mu \mathrm{m})$.

density of the granular layer. The pyramidal cells are irregular, shrinked, deeply stained and loosely packed with spaces around and in between them. Many cells have irregular nuclei and others with pyknotic and fragmented ones with basophilic cytoplasm. The nuclei of the glial cells are prominent (Figures 1c and 1d).

In $(\mathrm{Ag}+\mathrm{GT})$ group, some small pyramidal cells show nor- mal appearance while others appear with deeply stained and fragmented nuclei (Figure 1e). Some degenerated large pyramidal cells between the preserved small cells and glial cells are observed. The preserved pyramidal cells appear with thick processes, vesicular nuclei and basophilic cytoplasm rich in Nissl's granules (Figure 1f).

In $(\mathrm{Ag}+\mathrm{Gr})$ group, there is an increase in the thickness of pyramidal layer. Large number of normally preserved small pyramidal cells with vesicular nuclei and basophilic granular cytoplasm are detected. Some cells are still shrinked with deeply stained cytoplasm. Normal glial cells with vesicular nuclei are clearly observed (Figure $1 \mathrm{~g}$ ). A lot of deeply stained shrunken large pyramidal cells are observed in Figure $\mathbf{1 h}$. These cells have thick processes while others show normal vesicular rounded nuclei, basophilic granular cytoplasm and processes. Glial cells are normally present.

In female rats, the pyramidal cells are variable in sizes (small and large)in (y. cont.) group. These cells have vesicular nuclei; basophilic granular cytoplasm rich with Nissl's granules and prominent processes. Glial cells in molecular layer and in between the pyramidal cells are observed (Figures $\mathbf{2} \mathbf{a}$ and $\mathbf{2 b}$ ).

In Ag group,there is apparent decrease in the thickness of the small pyramidal cells. The majority of the cells are irregular and deeply stained. Few cells have rounded vesicular nuclei and basophilic cytoplasm. Glial cells are observed (Figure 2c). Large pyramidal cells are shrinked, while some of them appear with deeply stained nuclei and others have fragmented nuclei (Figure $\mathbf{2 d}$ ).

In Ag+GT group,many small pyramidal cells are shrunken and deeply stained. Other cells appear with rounded vesicular nuclei and basophilic granules. Normal glial cells are present (Figure 2e). Few large pyramidal cells are preserved and appear loosely packed. Other pyramidal cells are shrunken with increase spaces around them (Figure 2f).

In general, the architecture of the hippocampus of $\mathrm{Ag}+\mathrm{Gr}$ group appears nearly like that in (y.cont.) group. Small pyramidal cells are normally preserved. These cells have rounded vesicular nuclei and basophilic granular cytoplasm while few cells are shrinked (Figure 2g). Many large pyramidal cells are preserved but still others have deeply stained cytoplasm and nuclei. Normal glial cells are present (Figure $\mathbf{2 h}$ ).

Measurement of lipid peroxidation (LPO) in the serum In male rats, the quantitative results are present in Table 1. In aged rats the level of lipid peroxidation (LPO) was increased (122.5\%) significantly $(P<0.001)$ versus those of (y.cont.) group (as indicated by the increase in Malondialdehyde [MDA] levels). In (Ag+GT) group, decrease in the level of LPO (63.88\%) occurred when compared with those of Ag group. This inhibition was statistically significant $(P<0.001)$. When compared with $y$. cont. group levels, there was non- significant difference between them (Table 1).

Garlic administration to aged rats $(\mathrm{Ag}+\mathrm{Gr})$ also decreased (53.64\%) the level of LPO significantly $(P<0.001)$ than those of 

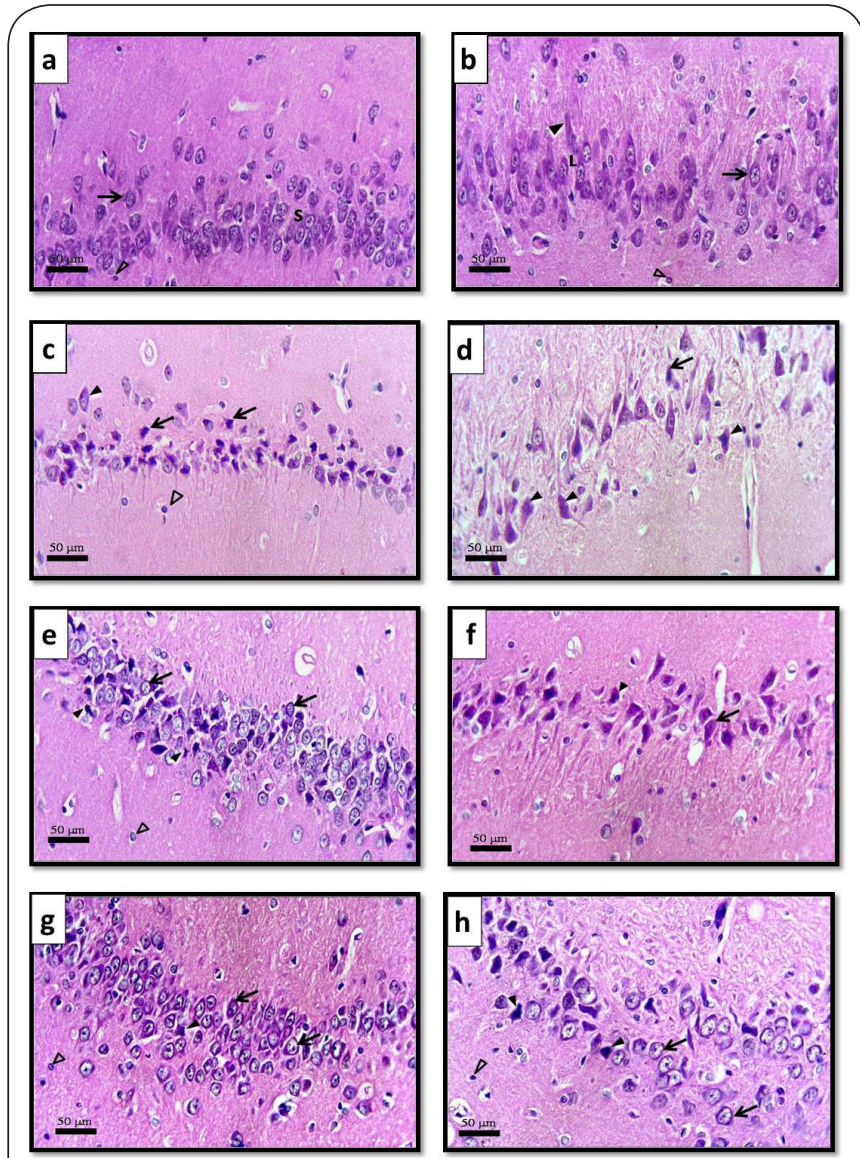

Figure 2. Photomicrographs of hippocampus proper of female rats, (a and b) for y.cont. group: small (S) and larg (L) pyramidal cells with round vesicular nuclei and basophilic granular cytoplasm with Nissl's granules $(\uparrow)$, cell processes $(\boldsymbol{\Delta})$ and glial cells $(\Delta)$. (c and $\mathbf{d})$ for Ag group. c: irregular cells, deeply stained with irregular nuclei $(\uparrow)$, few pyramidal cells with rounded vesicular nuclei $(\boldsymbol{\Delta})$ and glial cells $(\Delta)$. d: shrinked large pyramidal cells $(\uparrow)$, some cells are with deeply stained nuclei, other with fragmented nuclei $(\boldsymbol{\Delta})$. (e and f f) for Ag+GT group. e: many shrunken and deeply stained small pyramidal cells $(\boldsymbol{\Delta})$,other cells with rounded vesicular nuclei and basophilic granular cytoplasm $(\uparrow)$ and many glial cells are present $(\Delta)$. f: preserved large pyramidal cells $(\uparrow)$,others are shrunken with increase in space around them $(\boldsymbol{\Lambda})$. (g and $\mathbf{h})$ for Ag+Gr group. g: preserved small pyramidal cells ( $\uparrow$ ), few cells are shrinked $(\boldsymbol{\Delta})$ and many glial cells $(\Delta)$. h: preserved large pyramidal cells $(\uparrow)$, few cells with deeply stained cytoplasm and nuclei $(\boldsymbol{\Delta})$ and many glial cells $(\Delta)(\mathrm{H} \& \mathrm{E}$, Bar $=50 \mu \mathrm{m})$.

Ag group. There was a non-significant difference in the LPO level when compared with those of (y.cont.) group (Table 1).

There was non-significant differences occurred in the level of $\mathrm{LPO}$ between $(\mathrm{Ag}+\mathrm{GT})$ and $(\mathrm{Ag}+\mathrm{Gr})$ groups (Table 1).

In female rats, as shown in Table 1, there was an increase in oxidized lipids in aged rats (48.5\%) versus those of $y$. cont. ones. Statistically, this increase was non-significant.

In (Ag+GT and $\mathrm{Ag}+\mathrm{Gr})$ groups, green tea and garlic admin- istration did not exert any significant differences in the level of $L P O$ versus those in Ag group. When comparing with those of (y.cont) group, there was a significant increase $(P<0.001)$ present in the level of LPO in both treated groups (Table 1).

The comparison between the two treated groups ( $\mathrm{Ag}+\mathrm{GT}$ and $\mathrm{Ag}+\mathrm{Gr}$ ) revealed that no significant differences present in the level of LPO between them (Table 1).

In comparison between the level of LPO of male and female rats, in y.cont.group there was non-significant difference between males and females. In Ag group, the LPO level increased $(47.87 \%)$ significantly $(\mathrm{P}<0.05)$ in males than females. In Ag+GT groups, the level decreased (59.94\%) significantly $(P<0.001)$ in males than those of females. Also, significant $(P<0.001)$ decrease $(48.99 \%)$ was detected in the level of $L P O$ of the male rats of $\mathrm{Ag}+\mathrm{Gr}$ group than females of the same group (Table 1).

\section{Measurement of Superoxide dismutase (SOD) activity in the serum}

In male rats, the quantitative results are present in Table 2. In aged rats the activity of Superoxide dismutase (SOD) decreased $(52.77 \%)$ significantly $(P<0.05)$ versus those of young control group.

Green tea administration to aged rats $(\mathrm{Ag}+\mathrm{GT})$ increased the activity of SOD $(67.53 \%)$ significantly $(P<0.001)$ when compared with Ag group. When compared with y.cont. group, there was a significant $(P<0.001)$ decrease in the SOD activity (Table 2).

In $(\mathrm{Ag}+\mathrm{Gr})$ group, garlic stimulated the activity of SOD $(81.84 \%)$ significantly $(P<0.001)$ versus those of $\mathrm{Ag}$ group. There was a significant decrease $(P<0.001)$ in the SOD activity when compared with y.cont. group ones (Table 2).

Non-significant increase (8.53\%) occurred in the activity of SOD in $\mathrm{Ag}+\mathrm{Gr}$ group versus those of $\mathrm{Ag}+\mathrm{GT}$ groups (Table 2).

In female rats, as shown in Table 2, the activity of SOD decreased $(39.50 \%)$ significantly $(P<0.001)$ in $A g$ group versus those of (y.cont.) group.

Green tea administration to aged rats increased the activity of SOD significantly $(P<0.001)$ by $55.67 \%$ when compared with Ag group. Non-significant differences occurred in the activity of SOD versus those of (y.cont.) group (Table 2).

In Ag+Gr group, the activity of SOD increased (1.77\%) versus those in Ag group. Statistically, this stimulation was non-significant. When comparing with y.cont., there was significant $(P<0.001)$ decrease in the activity of SOD occurred between them (Table 2).

Between (Ag+GT and Ag+Gr) groups, there was a nonsignificant decrease in the level of SOD (34.58\%) in Ag+Gr versus those of $\mathrm{Ag}+\mathrm{GT}$ (Table 2).

In comparison between the activity of SOD in male and female rats, in (y.cont.) group there was significant decrease $(\mathrm{P}<0.001)$ by $52.65 \%$ between males and females. In Ag group, there was non-significant difference between the two genders. In Ag+GT group, the activity of SOD increased 
Table 1. Mean values \pm SE of lipid peroxidation (MDA), stimulation and/or inhibition $\%$ in young, aged and aged-treated male and female rats.

\begin{tabular}{|c|c|c|c|c|c|}
\hline 7 & & ale & & male & \\
\hline $\mathrm{G}$ & $\begin{array}{c}\text { MDA } \\
\text { (n mol/mg } \\
\text { protein) }\end{array}$ & $\begin{array}{l}\text { Inhibition \% (I) } \\
\text { Or } \\
\text { Stimulation \%(S) }\end{array}$ & $\begin{array}{l}\text { MDA } \\
\text { (n } \mathrm{mol} / \mathrm{mg} \\
\text { protein) }\end{array}$ & $\begin{array}{l}\text { Inhibition\% (I) } \\
\text { or } \\
\text { Stimulation\%(S) }\end{array}$ & ठv. vs. + \\
\hline y. cont & $0.3025 \pm 0.051^{\mathrm{a}}$ & - & $0.3064 \pm 0.041^{\mathrm{a}}$ & - & $P>0.05$ \\
\hline $\mathrm{Ag}$ & $0.673 \pm 0.044^{b}$ & $\mathrm{~S}=122.47 \mathrm{vs} . \mathrm{y}$. cont. & $0.4551 \pm 0.032^{a b}$ & $S=48.53$ vs. y.cont. & $P<0.05$ \\
\hline $\mathrm{Ag}+\mathrm{GT}$ & $0.2431 \pm 0.019^{\mathrm{ac}}$ & $\mathrm{I}=63.88 . \mathrm{vs} . \mathrm{Ag}$ & $0.6067 \pm 0.041^{b}$ & $\mathrm{~S}=33.31 \mathrm{vs} . \mathrm{Ag}$ & $P<0.001$ \\
\hline $\mathrm{Ag}+\mathrm{Gr}$ & $0.312 \pm 0.021^{\mathrm{ac}}$ & $\begin{array}{l}\mathrm{I}=53.64 \text { vs. } \mathrm{Ag} \\
\mathrm{S}=28.34 \text { vs. } \mathrm{Ag}+\mathrm{GT}\end{array}$ & $0.6117 \pm 0.106^{b}$ & $\begin{array}{l}\mathrm{S}=34.41 \text { vs. } \mathrm{Ag} \\
\mathrm{S}=0.824 \mathrm{vs} . \mathrm{Ag}+\mathrm{GT}\end{array}$ & $P<0.001$ \\
\hline
\end{tabular}

Values in the same column with unlike superscript letters are significantly different at $\mathrm{P}<0.05$.

Table 2. Mean values \pm SE of Superoxide dismutase (SOD), stimulation and/or inhibition \% in young, aged and aged-treated male and female rats.

\begin{tabular}{|c|c|c|c|c|c|}
\hline \multirow[t]{2}{*}{1} & \multicolumn{2}{|c|}{ Male } & \multicolumn{2}{|c|}{ Female } & \multirow[b]{2}{*}{ ठैvs. $q$} \\
\hline & $\begin{array}{c}\text { SOD } \\
\mathrm{U} / \mathrm{min} . / \mathrm{mg} \\
\text { protein }\end{array}$ & $\begin{array}{c}\text { Inhibition \%(I) } \\
\text { Or } \\
\text { Stimulation \%(S) }\end{array}$ & $\begin{array}{c}\text { SOD } \\
\mathrm{U} / \mathrm{min} . / \mathrm{mg} \\
\text { protein }\end{array}$ & $\begin{array}{c}\text { Inhibition\% (I) } \\
\text { or } \\
\text { Stimulation\%(S) }\end{array}$ & \\
\hline y. cont & $285.6 \pm 8.246^{\mathrm{a}}$ & - & $187.1 \pm 5.774^{\mathrm{a}}$ & - & $P<0.05$ \\
\hline $\mathrm{Ag}$ & $134.9 \pm 6.654^{b}$ & I=52.77 vs.y.cont. & $113.2 \pm 7.508^{\circ}$ & $\mathrm{I}=39.50$ vs. y.cont. & $P>0.05$ \\
\hline $\mathrm{Ag}+\mathrm{GT}$ & $226 \pm 5.774^{\mathrm{C}}$ & $\mathrm{S}=67.53 \mathrm{vs} . \mathrm{Ag}$ & $176.1 \pm 5.774^{\mathrm{a}}$ & $\mathrm{S}=55.57 \mathrm{vs} . \mathrm{Ag}$ & $P<0.05$ \\
\hline $\mathrm{Ag}+\mathrm{Gr}$ & $245.3 \pm 5.78^{c}$ & $\begin{array}{l}\mathrm{S}=81.84 \text { vs. } \mathrm{Ag} \\
\mathrm{S}=8.53 \text { vs. } \mathrm{Ag}+\mathrm{GT}\end{array}$ & $115.2 \pm 8.663^{\circ}$ & $\begin{array}{l}\mathrm{S}=1.77 \text { vs. } \mathrm{Ag} \\
\mathrm{I}=34.58 \text { vs. } \mathrm{Ag}+\mathrm{GT}\end{array}$ & $P<0.05$ \\
\hline
\end{tabular}

Values in the same column with unlike superscript letters are significantly different at $\mathrm{P}<0.05$.

(28.34\%) significantly $(\mathrm{P}<0.001)$ in male rats than female ones. The Garlic administration to aged rats increased the activity of SOD $(112.93 \%)$ significantly $(P<0.001)$ in male rats versus females (Table 2).

\section{Measurement of Glutathione (GSH) concentration in} the serum

In male rats, the quantitative results are present in Table 3 . In aged rats the concentration of glutathione (GSH) decreased $(70.72 \%)$ significantly $(\mathrm{P}<0.05)$ versus those of $(y . c o n t$.$) group.$ In $(\mathrm{Ag}+\mathrm{GT})$ group, green tea administration increased the concentration of GSH $(17.34 \%)$ significantly $(P<0.01)$ when compared with those of Ag group. When compared with $y$.cont. group, there was a significant decrease $(P<0.001)$ in

\section{GSH concentration (Table 3 ).}

Garlic administration to aged rats $(\mathrm{Ag}+\mathrm{Gr})$ also increased significantly $(P<0.001)$ the GSH concentration by $125.84 \%$ versus those of $\mathrm{Ag}$ group. There was a significant decrease $(P<0.001)$ in the concentration of GSH when compared with y.cont.group ones (Table 3).

The comparison between the two treated groups ( $\mathrm{Ag}+\mathrm{GT}$ and $\mathrm{Ag}+\mathrm{Gr}$ ) revealed that the concentration of GSH was decreased $(92.46 \%)$ significantly $(P<0.001)$ in the animals given green tea $(\mathrm{Ag}+\mathrm{GT})$ versus those given garlic $(\mathrm{Ag}+\mathrm{Gr}$ ) (Table 3 ).

In female rats, as shown in Table 3 , the concentration of GSH decreased $(46.99 \%)$ significantly $(P<0.001)$ in Ag group versus those of (y.cont.) group.

Green tea administration to aged rats $(\mathrm{Ag}+\mathrm{GT})$ decreased 
Table 3. Mean values $\pm \mathrm{SE}$ of Glutathione (GSH), stimulation and/or inhibition $\%$ in young, aged and aged-treated male and female rats.

\begin{tabular}{|c|c|c|c|c|c|}
\hline Measurement & & ale & & male & \\
\hline Groups & $\begin{array}{c}\text { GSH } \\
\mu \mathrm{g} / \mathrm{mg} \text { protein }\end{array}$ & $\begin{array}{c}\text { Inhibition \% (I) } \\
\text { Or } \\
\text { Stimulation \%(S) }\end{array}$ & $\begin{array}{c}\text { GSH } \\
\mu \mathrm{g} / \mathrm{mg} \text { protein }\end{array}$ & $\begin{array}{c}\text { Inhibition\% (I) } \\
\text { or } \\
\text { Stimulation\%(S) }\end{array}$ & $\partial^{1}$ vs. $q$ \\
\hline y. cont & $166.8 \pm 2.144^{\mathrm{a}}$ & - & $119.1 \pm 2.613^{\mathrm{a}}$ & - & $P<0.001$ \\
\hline $\mathrm{Ag}$ & $48.8 \pm 2.891^{b}$ & I=70.72 vs.y.cont. & $63.1 \pm 2.598^{b}$ & $\mathrm{I}=46.99$ vs. y.cont. & $P<0.01$ \\
\hline $\mathrm{Ag}+\mathrm{GT}$ & $57.3 \pm 1.357^{\mathrm{C}}$ & $\mathrm{S}=17.34$ vs. $\mathrm{Ag}$ & $24.9 \pm 2.895^{\mathrm{c}}$ & $\mathrm{I}=60.58$ vs. $\mathrm{Ag}$ & $P<0.001$ \\
\hline $\mathrm{Ag}+\mathrm{Gr}$ & $110.3 \pm 2.903^{\mathrm{d}}$ & $\begin{array}{l}S=125.84 \text { vs. } A g \\
S=92.46 \text { vs. } A g+G T\end{array}$ & $29.1 \pm 2.888^{\mathrm{c}}$ & $\begin{array}{l}\mathrm{I}=53.96 \text { vs. } \mathrm{Ag} \\
\mathrm{S}=16.73 \mathrm{vs} . \mathrm{Ag}+\mathrm{GT}\end{array}$ & $P<0.001$ \\
\hline
\end{tabular}

Values in the same column with unlike superscript letters are significantly different at $\mathrm{P}<0.05$.

significantly $(\mathrm{P}<0.001)$ the GSH concentration $(60.58 \%)$ when compared with Ag group. Significant decrease $(P<0.01)$ also occurred in the concentration of GSH when compared with y.cont. group (Table 3).

The administration of aged rats with garlic $(\mathrm{Ag}+\mathrm{Gr}) \mathrm{de}$ creased $(53.96 \%)$ significantly $(P<0.001)$ the concentration of GSH when compared with Ag group. When comparing with (y.cont.) group, there was significant decrease $(P<0.001)$ in the GSH concentration (Table 3 ).

The comparison between the two treated groups ( $\mathrm{Ag}+\mathrm{GT}$ and $\mathrm{Ag}+\mathrm{Gr}$ ) revealed that there was non-significant differences occurred in the GSH concentration between them (Table 3).

In comparison between the concentration of GSH in male and female rats, there was a significant $(P<0.001)$ increase by $40.05 \%$ between them in young control group. In Ag group, GSH concentration increased significantly $(P<0.01)$ in females by $22.65 \%$ versus those in males. The administration of aged rats with green tea decreased significantly $(P<0.001)$ the $G S H$ concentration in males by (130.25\%) versus those of females. In $\mathrm{Ag}+\mathrm{Gr}$ group, there was significant $(\mathrm{P}<0.001)$ increase in the concentration of GSH by $279.43 \%$ in male rats versus female ones (Table 3).

\section{Discussion}

The simplest and the most popular region for studying the cortical network is the hippocampal CA1 area, because it has the least heterogeneous neuronal population, the somata and dendrites of principal neurons (pyramidal cells) are arranged into well-defined layers and the extrinsic and intrinsic inputs are segregated. The hippocampus is critically involved in learning and in memory formation for facts and events (explicit or declarative memory) [19].
In this study we focused on the hippocampus proper which is part of hippocampal formation. The hippocampal formation composed of dentate gyrus, subicumulus in addition to the hippocampus proper. The hippocampus proper is formed of Corno Ammonis, CA1 and CA2 formed of zone of small pyramidal cells which is the dominant neurons in the hippocampus proper, CA3 and CA4 formed of zones of large pyramidal cells [20].

The degenerative changes were observed in this study appeared in the form of small, dense and deeply stained pyramidal cells in the pyramidal layer. This finding was in line with [21] who explained that the age related degenerative changes occur as a result of oxidative modification of DNA, protein, lipids and cellular molecules by reactive oxygen species (ROS). The appearance of these degenerative changes in the hippocampus proper leads to the affection in the spatial memory-related learning ability as they the main function of hippocampus. This in agreement with the finding of [22] who suggested that, changes in learning ability may be associated with the degeneration of cholinergic neurons in the hippocampus. Ma et al. [23] reported that the brain is more affected by oxidative damage while antioxidants defense ability decrease due to aging.

The present study cleared that the administration of green tea improves the histological appearance of the pyramidal cells. The preserved pyramidal cells appear with thick processes, vesicular nuclei and basophilic cytoplasm rich in Nissl's granules. Our finding come in line with the conclusion of [24 and 25] they suggested that green tea catechins and epigallocatechingallate (EGCG) have a protective effect against age-related neurological disease associated with ROS, small intestine, the liver, and it can cross the blood brain barrier to 
lower the hippocampus reactive oxygen species concentration.

In the current study, garlic treated aged rats showed increase in the thickness of pyramidal layer and large number of normally preserved small pyramidal cells with vesicular nuclei and basophilic granular cytoplasm. These results confirmed previously by Borek [26].

The appearance of large number of glial cells with vesicular nuclei in both aged and treated groups in this study may explained as a compensatory role to preserve the neurons or help the affected neurons to perform their functions. This supported by the finding of [27] they cleared the role of glia and astrocytes in the activity of the neuronal networks. They showed that the microglia are activated in many neurodegentative diseases, adding that whether they are helpful or harmful. The involvement of glial cells in brain aging was recently studied by [28 and 29], They observed that the glial genes shift their regional expression patterns, while the microgliaspecific genes increase their expression upon aging.

In current study, there was a significant increase in the level of oxidized lipids in the serum of aged rats than that of those in young control group. In fact lipid peroxidation products have been used as indirect biomarkers of oxidative stress with aging [30]. According to [31], there is a great deal of interest in lipid peroxidation in terms of evaluating its importance as a primary mechanism of tissue injury and deterioration of a wide variety of cellular enzymes resulting in neurodegenerative process. Also, our results showed that in aged males the level of LPO in the serum was more than that in females. This may result from the protective role of estrogen against agerelated diseases due to estrogen replacement [32].

In the present study, the administration of the aged male rats with green tea decrease the level of LPO significantly when compared with those of Aged group. When compared with y. cont. group levels, there was non- significant difference between them. The previous studies of $[33,34]$ reported that GT reduces oxidative stress by virtue of its antioxidant properties thus improving the structural integrity of cell membrane and eventually alleviates the histopathological changes as well as the biochemical perturbations. These results suggest that catechins, epicatechin (EC), epigallocatechin (EGC), epicatechin-3-gallate (ECG), and EGCG could have a direct (antioxidant) or indirect (increase of activity or expression) effect $[35,36]$.

In our study, Garlic administration to aged male rats also decreased the level of LPO significantly than those of Ag group and there were non-significant differences when compared with those of y. cont. group. This result conform the result of [37] who observed that phytochemical from plant-rich diets, including garlic, provide important additional protection against oxidant damage. Garlic extract supplementation improves blood lipid profile, strengthens blood antioxidant potential, and also leads to a decrease in the level of oxidation product (MDA) in the blood samples, which demonstrates reduced oxidation reactions in the body $[38,39]$.
[40] found that SOD activities were decreased with aging Oxidative stress -which is results from aging in our study- is defined as a disturbance in the balance between the production of ROS and antioxidant defense systems as SOD. This result comes in line with our data which showed that the activity of Superoxide dismutase (SOD) in aged male and female rats decreased significantly versus those of young control group.

[41] suggested that different models of oxidative stress involve a biphasic response of the antioxidant enzyme activities. First, the enzymatic activities are markedly decreased but at longer times, in response to oxidative stress. Secondary, the activity levels are increased probably as a consequence of de novo synthesis or enzymatic activation. Our results are in agreement with this author in his first suggested phase.

In the current study, Green tea administration to aged male and female rats increased the activity of SOD when compared with Aged groups. These data confirmed by [42] they said that SOD plays an important role in attenuating oxidative damage in vivo, thereby delaying not only the onset of age-related degenerative disease, but also aging itself. In vivo study made by [43] intake of green tea extracts also increase the activity of superoxide dismutase in serum and the expression of catalase, these enzymes play a role in cellular protection against reactive oxygen species.

The administration of Garlic to aged male rats stimulated the activity of SOD significantly versus those of Ag group. These results are in agreement with many studies [44,45] who found that dietary supplement of garlic extract activated the antioxidant system and decreased peroxidation in aortic tissue in their experimental model. The water-soluble organo-sulfur compounds of garlic including S-allyl cysteine, S-allylmercaptocyteine, allicin, and selenium exhibited potent antioxidant and free radical scavenging activities in vitro and in vivo $[46,47]$.

Our results revealed decrease in the concentration of glutathione (GSH) in aged male and female rats significantly versus those of young control group. These results come in agreements with [48] who suggested that a GSH-deficiency state is a general phenomenon in aging cells, organisms and tissues in rats due to a lack of the precursor amino acid, cysteine. Our results also showed that in Ag group, GSH concentration increased significantly in females versus those in males.

These results confirmed by [49] who found that the GSH levels in the females at 24 months were significantly higher than in the males. The reason for these gender-dependent differences in the maintenance of GSH levels during maturation and aging may be related to estrogen levels. Assuming that, this data is relevant to humans, an increase in g-glutamyltranspeptidase activity could account for a decreased GSH due to increased its degradation, decreased release from tissues, either as a consequence of decreased intracellular concentrations or due to decreased GSH transporter functions with aging [50].

In our study, the administration of the aged male rats with green tea and garlic increased the concentration of GSH 
significantly when compared with those of Ag group. According to the finding of the present investigation, dietary supplementation of polyphenol-rich berries in transgenic mice was shown to modulate the expression of the catalytic subunit of $\gamma$-glutamylcysteine synthetase, leading to a significant increase in total glutathione concentrations in various organs [51].

The ability of garlic to enhance glutathione peroxidase, ROS scavenging may and provide protection from chronic diseases associated with disease and aging processes in liver and mammary tissue [52]. GSH is oxidized to its disulphide form, GSSG, which is then reduced back to GSH by GSSG-reductase. Garlic increased the intracellular level of GSH, decreased the intracellular level of GSSG, and increased the activity of GSSG-reductase and SOD [53]. The increased GSSG-reductase activity induced by garlic would accelerate regeneration of GSH from GSSG. This may explain the increase of intracellular GSH in the study.

Our results found that the protective role of green tea and garlic against the deterioration in the oxidative stress parameters were obvious in males than females, that may be resulted from the deficiency in the estrogen in aged females after menopause which play a protective role against oxidative stress and in turn triggering a lot of health problem in females [54].

\section{Conclusion}

Our results showed that the protective role of green tea and garlic against oxidative stress parameters was more effective in males than females. Morphologically, garlic exerted preservation to the pyramidal cells of hippocampus more than green tea in both genders. This study suggests that the use of both green tea and garlic may inhibit the bodily changes associated with aging.

\section{Competing interests}

The authors declare that they have no competing interests.

\section{Authors' contributions}

\begin{tabular}{|l|c|c|c|}
\hline Authors' contributions & GHE & AAA & MMA \\
\hline Research concept and design & $\checkmark$ & $\checkmark$ & -- \\
\hline Collection and/or assembly of data & $\checkmark$ & $\checkmark$ & -- \\
\hline Data analysis and interpretation & $\checkmark$ & $\checkmark$ & -- \\
\hline Writing the article & $\checkmark$ & $\checkmark$ & $\checkmark$ \\
\hline Critical revision of the article & $\checkmark$ & $\checkmark$ & $\checkmark$ \\
\hline Final approval of article & $\checkmark$ & $\checkmark$ & -- \\
\hline Statistical analysis & $\checkmark$ & $\checkmark$ & -- \\
\hline
\end{tabular}

Publication history

EIC: Gaetano Giuseppe Magro, University of Catania, Italy.

Received: 03-April-2018 Final Revised: 03-May-2018

Accepted: 10-May-2018 Published: 17-May-2018

\section{References}

1. Sohal RS, Mockett RJ and Orr WC. Mechanisms of aging: an appraisal of the oxidative stress hypothesis. Free Radic Biol Med. 2002; 33:575-86. | Article I PubMed
2. Harman D. Aging: a theory based on free radical and radiation chemistry. J Gerontol. 1956; 11:298-300. | PubMed

3. Maynard S, Schurman SH, Harboe C, de Souza-Pinto NC and Bohr VA. Base excision repair of oxidative DNA damage and association with cancer and aging. Carcinogenesis. 2009; 30:2-10. I Article I PubMed Abstract | PubMed FullText

4. Hamilton ML, Van Remmen H, Drake JA, Yang H, Guo ZM, Kewitt K, Walter CA and Richardson A. Does oxidative damage to DNA increase with age? Proc Natl Acad Sci U S A. 2001; 98:10469-74. | Article | PubMed Abstract | PubMed FullText

5. Andersen $\mathrm{P}$, editor. The hippocampus book. Oxford university press. 2007.

6. Langston RF, Stevenson $\mathrm{CH}$, Wilson $\mathrm{CL}$, Saunders I and Wood ER. The role of hippocampal subregions in memory for stimulus associations. Behav Brain Res. 2010; 215:275-91. | Article I PubMed

7. Petropoulos S, Di Gioia F and Ntatsi G. Vegetable Organosulfur Compounds and their Health Promoting Effects. Curr Pharm Des. 2017; 23:2850-2875. | Article | PubMed

8. Banerjee SK, Maulik M, Manchanda SC, Dinda AK, Das TK and Maulik SK. Garlic-induced alteration in rat liver and kidney morphology and associated changes in endogenous antioxidant status. Food Chem Toxicol. 2001; 39:793-7. | Article | PubMed

9. Xu Y, Zhang JJ, Xiong L, Zhang L, Sun D and Liu H. Green tea polyphenols inhibit cognitive impairment induced by chronic cerebral hypoperfusion via modulating oxidative stress. J Nutr Biochem. 2010; 21:741-8. | Article I PubMed

10. Nugala B, Namasi A, Emmadi P and Krishna PM. Role of green tea as an antioxidant in periodontal disease: The Asian paradox. J Indian Soc Periodontol. 2012; 16:313-6. | Article | PubMed Abstract | PubMed FullText

11. Intra J and Kuo SM. Physiological levels of tea catechins increase cellular lipid antioxidant activity of vitamin $\mathrm{C}$ and vitamin $\mathrm{E}$ in human intestinal caco-2 cells. Chem Biol Interact. 2007; 169:91-9. I Article I PubMed Abstract | PubMed FullText

12. Gad SB and Zaghloul DM. Beneficial effects of green tea extract on liver and kidney functions, ultrastructure, lipid profile and hematological parameters in aged male rats. Global Vet. 2013; 11:191-205.

13. Mohamadin AM, Mariee AD, El-Hefnawy HM and Fath El-Bab M. Hypoglycemic activity of green tea extract in streptozotocin induced diabetic rats. Arab J Lab Med. 2003; 29:397-400.

14. Samar A A and Shireen A M. Distribution of Cyclooxygenase-2 (COX- 2) in the Liver of Adult Male Albino Rats after Supplementation of Sodium Arsenite with or without Allium Sativum(Garlic). Egypt. J. Histol. 2010; 33:541-551.

15. Carleton HM, Drury RAB and Wallington EA. Carleton's histological technique. Oxford University Press, USA. 1980.

16. Wills ED. Lipid peroxide formation in microsomes. Relationship of hydroxylation to lipid peroxide formation. Biochem J. 1969; 113:333-41. | Article | PubMed Abstract | PubMed FullText

17. Misra HP and Fridovich I. The role of superoxide anion in the autoxidation of epinephrine and a simple assay for superoxide dismutase. J Biol Chem. 1972; 247:3170-5. | Article | PubMed

18. Ravi K, Ramachandran B and Subramanian S. Effect of Eugenia Jambolana seed kernel on antioxidant defense system in streptozotocin-induced diabetes in rats. Life Sci. 2004; 75:2717-31. | Article I PubMed

19. Szilagyi T, Orban-Kis K, Horvath E, Metz J, Pap Z and Pavai Z. Morphological identification of neuron types in the rat hippocampus. Rom J Morphol Embryol. 2011; 52:15-20. I Pdf I PubMed

20. Amin SN, Younan SM, Youssef MF, Rashed LA and Mohamady I. A histological and functional study on hippocampal formation of normal and diabetic rats. F1000Res. 2013; 2:151. | Article | PubMed Abstract | PubMed FullText

21. Borek C. Antioxidants and cancer. Sci. Med. 1997; 4:51-62.

22. Fischer W, Chen KS, Gage FH and Bjorklund A. Progressive decline in spatial learning and integrity of forebrain cholinergic neurons in rats 
during aging. Neurobiol Aging. 1992; 13:9-23. | Article | PubMed

23. Ma L, Liu J, Li N, Wang J, Duan Y, Yan J, Liu H, Wang H and Hong F. Oxidative stress in the brain of mice caused by translocated nanoparticulate TiO2 delivered to the abdominal cavity. Biomaterials. 2010; 31:99-105. | Article | PubMed

24. Komatsu $M$ and Hiramatsu M. The efficacy of an antioxidant cocktail on lipid peroxide level and superoxide dismutase activity in aged rat brain and DNA damage in iron-induced epileptogenic foci. Toxicology. 2000; 148:143-8. | Article | PubMed

25. Haque AM, Hashimoto M, Katakura M, Tanabe Y, Hara Y and Shido O. Long-term administration of green tea catechins improves spatial cognition learning ability in rats. J Nutr. 2006; 136:1043-7. | Article | PubMed

26. Borek C. Antioxidant health effects of aged garlic extract. J Nutr. 2001; 131:1010S-5S. | Article | PubMed

27. Araque $A$ and Navarrete $M$. Glial cells in neuronal network function. Philos Trans R Soc Lond B Biol Sci. 2010; 365:2375-81. | Article | PubMed Abstract | PubMed FullText

28. Wynne AM, Henry CJ, Huang Y, Cleland A and Godbout JP. Protracted downregulation of CX3CR1 on microglia of aged mice after lipopolysaccharide challenge. Brain Behav Immun. 2010; 24:1190-201. | Article | PubMed Abstract | PubMed FullText

29. Soreq L, Rose J, Soreq E, Hardy J, Trabzuni D, Cookson MR, Smith C, Ryten M, Patani R and Ule J. Major Shifts in Glial Regional Identity Are a Transcriptional Hallmark of Human Brain Aging. Cell Rep. 2017; 18:557570. | Article | PubMed Abstract | PubMed FullText

30. Birben E, Sahiner UM, Sackesen C, Erzurum S and Kalayci O. Oxidative stress and antioxidant defense. World Allergy Organization Journal. 2012; 5:9.

31. Yatin SM, Varadarajan S, Link CD and Butterfield DA. In vitro and in vivo oxidative stress associated with Alzheimer's amyloid beta-peptide (142). Neurobiol Aging. 1999; 20:325-30. | Article | PubMed

32. Borras C, Sastre J, Garcia-Sala D, Lloret A, Pallardo FV and Vina J. Mitochondria from females exhibit higher antioxidant gene expression and lower oxidative damage than males. Free Radic Biol Med. 2003; 34:546-52. | Article | PubMed

33. Finkel T and Holbrook NJ. Oxidants, oxidative stress and the biology of ageing. Nature. 2000; 408:239-47. | Article | PubMed Abstract | PubMed FullText

34. Heikal TM, Mossa A T H, Rasoul M A A and MAREI GI K. The ameliorating effects of green tea extract against cyromazine and chlorpyrifos induced liver toxicity in male rats. Changes. 2013; 5:9.

35. Yokozawa T, Nakagawa T and Kitani K. Antioxidative activity of green tea polyphenol in cholesterol-fed rats. J Agric Food Chem. 2002; 50:3549-52. | Article | PubMed

36. Lambert JD and Elias RJ. The antioxidant and pro-oxidant activities of green tea polyphenols: a role in cancer prevention. Arch Biochem Biophys. 2010; 501:65-72. | Article | PubMed Abstract | PubMed FullText

37. Avci A, Atli T, Erguder IB, Varli M, Devrim E, Aras S and Durak I. Effects of garlic consumption on plasma and erythrocyte antioxidant parameters in elderly subjects. Gerontology. 2008; 54:173-6. | Article | PubMed

38. Rahman MM, Fazlic $V$ and Saad NW . Antioxidant properties of raw garlic (Allium sativum) extract. 2012. | Pdf

39. Mostafa RM, Moustafa YM, Mirghani Z, AlKusayer GM and Moustafa KM. Antioxidant effect of garlic (Allium sativum) and black seeds (Nigella sativa) in healthy postmenopausal women. SAGE Open Med. 2013; 1:2050312113517501. | Article | PubMed Abstract | PubMed FullText

40. Chang D, Zhang X, Rong S, Sha Q, Liu P, Han T and Pan H. Serum antioxidative enzymes levels and oxidative stress products in agerelated cataract patients. Oxid Med Cell Longev. 2013; 2013:587826. | Article I PubMed Abstract I PubMed FullText

41. Travacio $M$ and Llesuy $S$. Antioxidant enzymes and their modification under oxidative stress condition. Journal of British Association for the Advancement of Science. 1996; 48:9-13.

42. Lin $Y \mathrm{~L}$, Cheng $C Y$, Lin $Y \mathrm{P}$, Lau $Y \mathrm{~W}$, Juan I M and Lin J K.
Hypolipidemic effect of green tea leaves through induction of antioxidant and phase II enzymes including superoxide dismutase, catalase, and glutathione S-transferase in rats. Journal of Agricultural and food chemistry. 1998; 46:1893-1899. | Article

43. Skrzydlewska E, Ostrowska J, Farbiszewski R and Michalak K. Protective effect of green tea against lipid peroxidation in the rat liver, blood serum and the brain. Phytomedicine. 2002; 9:232-8. | Article | PubMed

44. Chen HW, Tsai CW, Yang JJ, Liu CT, Kuo WW and Lii CK. The combined effects of garlic oil and fish oil on the hepatic antioxidant and drugmetabolizing enzymes of rats. Br J Nutr. 2003; 89:189-200.

45. Durak I, Kavutcu M, Aytac B, Avci A, Devrim E, Ozbek H and Ozturk HS. Effects of garlic extract consumption on blood lipid and oxidant/ antioxidant parameters in humans with high blood cholesterol. J Nutr Biochem. 2004; 15:373-7. | Article | PubMed

46. Capasso A. Antioxidant action and therapeutic efficacy of Allium sativum L. Molecules. 2013; 18:690-700. | Article | PubMed

47. Nasr AY. Protective effect of aged garlic extract against the oxidative stress induced by cisplatin on blood cells parameters and hepatic antioxidant enzymes in rats. Toxicol Rep. 2014; 1:682-691. | Article | PubMed Abstract | PubMed FullText

48. Richie JP, Jr. The role of glutathione in aging and cancer. Exp Gerontol. 1992; 27:615-26. | PubMed

49. Wang $\mathrm{H}$, Liu $\mathrm{H}$ and Liu RM. Gender difference in glutathione metabolism during aging in mice. Exp Gerontol. 2003; 38:507-17. | Article | PubMed

50. Ookhtens $M$ and Mittur AV. Developmental changes in plasma thioldisulfide turnover in rats: a multicompartmental approach. Am J Physiol. 1994; 267:R415-25. | Article | PubMed

51. Basu A, Betts NM, Mulugeta A, Tong C, Newman E and Lyons TJ. Green tea supplementation increases glutathione and plasma antioxidant capacity in adults with the metabolic syndrome. Nutr Res. 2013; 33:1807. | Article | PubMed Abstract | PubMed FullText

52. Borek C. Antioxidant health effects of aged garlic extract. J Nutr. 2001; 131:1010S-5S. | Article | PubMed

53. Geng $\mathrm{Z}$ and Lau BH. Aged garlic extract modulates glutathione redox cycle and superoxide dismutase activity in vascular endothelial cells. Phytotherapy Research. 1997; 11:54-56. | Article

54. Horstman AM, Dillon EL, Urban RJ and Sheffield-Moore M. The role of androgens and estrogens on healthy aging and longevity. J Gerontol A Biol Sci Med Sci. 2012; 67:1140-52. | Article | PubMed Abstract | PubMed FullText

Citation:

El-Sokkary GH, I. Alghriany ASA and Atia MM. Protictive effects of green tea and garlic on the morphological and oxidative stress changes of hippocampus in aged male and female albino rats. J Histol Histopathol. 2018; 5:8. http://dx.doi.org/10.7243/2055-091X-5-8 